\title{
Abstracts
}

\section{Thorsten Bonacker}

\section{Global Victimhood}

On the Charisma of the Victim in Transitional Justice

ZIB, Vol. 19, No. 1, pp. 5-36

Since the 1990s, Transitional Justice has become almost equivalent to the concern of seeing that victims experience justice. In comparison to the Nuremberg Trials where victims could not even appear as witnesses - there has been a major shift that needs to be explained. In order to do this the following contribution is drawing on a macro-sociological research perspective. I will argue that the general shift to a wider inclusion of victims within Transitional Justice can be understood as the consequence of an expanding rationalistic world culture that creates a global pattern of victimhood which is primarily propagated via international organizations and nongovernmental organizations. The advocating action of (I)NGOs and the scientific understanding of trauma developed after Second World War is leading to a normative pressure on national Transitional Justice processes to make sure that victims are at the center stage of dealing with the past.

Keywords: victim, transitional justice, world polity, human rights, trauma.

\section{Michael Blauberger/Tilman Krüger/Susanne K. Schmidt}

\section{The Path-Dependency of International Legalization}

Comparing EU and WTO

ZIB, Vol. 19, No. 1, pp. 37-63

Taking a historical-institutionalist perspective, the present contribution explores the conditions under which international courts promote international legalization even against the opposition of national governments. Starting from the European Court of Justice's (ECJ) interpretation of the provisions on the free movement of goods, we show how judicial solutions found in one policy area are transferred to other areas, even though the functional needs may be different. This path-dependent judicial reasoning reinforces the internationalization of law. In order to explore the preconditions and limits of such processes of internationalization, we add two comparative cases to our analysis: we investigate the ECJ's solutions in the area of capital movement (EU-internal comparison) and we examine the role of the judiciary in the World Trade Organization (WTO, external comparison). We find that a steady caseload is necessary for precedent-based judicial decisions to develop momentum 
and that private and supranational actors have to take up the case law to reinforce its dynamic in a positive manner.

Keywords: european court of justice, historical institutionalism, international legalization, path-dependency, world trade organization dispute settlement.

\section{Ulrich Franke/Ulrich Roos}

\section{On Undesired Consequences of Action in International Relations}

ZIB, Vol. 19, No. 1, pp. 65-84

The article deals with the practice of International Relations (IR) as a sub-discipline of political science. It is based on two assumptions: i) IR has witnessed an increasing theoretical diversification in the course of the real-world changes after the end of the >Cold War<; ii) this development has not only brought about new possibilities but also new challenges for the IR community. These challenges are conceived as undesired consequences of contemporary IR's action. To reconstruct them and to propose possible alternatives is the major aim of this article.

Keywords: international relations, sociology of science, rules for action, indirect consequences of action, coherence.

\section{Thomas Bräuninger}

\section{Fertile Soil or Just a Desert?}

A Reply to Tina Freyburg

ZIB, Vol. 19, No. 1, pp. 85-102

In her contribution »Planting the Seeds of Change Inside?« (ZIB 18: 1, 5-46), Tina Freyburg argues that some forms of functional cooperation of democratic and authoritarian regimes can trigger subtle processes of democratization in the latter. One example is the change of attitudes of officials towards key principles of democratic governance once these officials have participated in transgovernmental cooperation networks under the framework of the European Union's Twinning program. The results of an analysis of survey data of officials is interpreted as evidence for the hypothesis. In this reply I discuss some of the methodological problems that come along with identifying and establishing causal mechanisms when dealing with quasi-experimental and observational data in general and Freyburg's study in particular.

Keywords: democratization, functional cooperation, primacy effect, causal inference, quasi-experimental design. 
Tina Freyburg

\section{When the Desert Blooms}

A Reply to Thomas Bräuninger

ZIB, Vol. 19, No. 1, pp. 103-120

In my article »Planting the Seeds of Change Inside?« (ZIB 18: 1, 5-46), I presented the findings of my study on the democratizing potential of transgovernmental policy networks that link sub-units of administrations from established democracies and authoritarian regimes to solve policy-specific problems. More precisely, I explored the extent to which and the way in which the European Union's Twinning projects can positively shape the attitudes toward democratic governance of involved state officials in a stable authoritarian regime such as Morocco. The results of multiple cross-sectional regression analyses based on original survey data show that transgovernmental networks can, under the condition of a prior stay abroad in an established democracy, socialize state officials into democratic governance in authoritarian regimes. In his reply, Thomas Bräuninger rightly reminds us of some of the methodological challenges in research on socialization. After having reanalyzed my data in the light of his concerns and suggestions, I still do find sufficient empirical evidence for the democratizing potential of functional cooperation in transgovernmental networks.

Keywords: causal inference, democratization, functional cooperation, international socialization, matching.

\section{Stephan Stetter/Carlo Masala/Sebastian Enskat \\ »One Big Happy Family«}

Introductory Remarks on the Relationship of IR and Peace and Conflict Studies ZIB, Vol. 19, No. 1, pp. 121-126

In this editorial comment, we argue that, at least to some degree, a disjuncture between IR and peace and conflict studies can currently be witnessed. Quite curiously, this disjuncture has to do with a shared similarity in mainstream approaches in both fields, namely an overtly liberalist understanding of politics. We point out that systematic bridge-building between both fields requires flagging out an intellectual horizon beyond such liberalist conceptions of global order and global conflict.

Keywords: international relations, peace and conflict studies, liberal peace, global order, security. 
Michael Brzoska

Peace Research and International Relations - in Praise of Difference ZIB, Vol. 19, No. 1, pp. 127-140

Peace Research and International Relations (IR) are - with different intensity and in different forms - closely related to each other for more than half a century. Peace Research cannot be thought of without IR, historically as well as currently. Peace Research was established in critical contrast to dominant IR approaches of the time. Many of the concepts that IR has intensively investigated since the 1990s had been raised in Peace Research earlier. The professionalization of Peace Research that can be detected since the 1990s has included the loan of research designs, exact methods and theory-building from IR. However, Peace Research and IR remain different in important respects, in particular value foundation, praxis orientation and their concepts of interdisciplinarity. Peace Research should not be understood as an academic discipline but rather combines approaches and methods from many disciplines with the goal to deliver academically sound analysis for the prevention and reduction of organized violence.

Keywords: peace research, international relations, conflicts, practice orientation, normativity.

\section{Klaus Schlichte}

International Relations as the Church, Peace and Conflict Studies as a Sect? Comments on the Discipline ZIB, Vol. 19, No. 1, pp. 141-152

Over the last ten years, Peace and Conflict Studies have experienced a certain boom in Germany, at least in terms of offered study programs. Do we see here the emergence of a new discipline? The answer put forward in this article is rather negative. In earlier decades, too, a number of rather critical IR scholars in Germany and beyond have worked in Peace and Conflict Studies, and current changes can thus be seen as a renewal of that interest. However, the scientific community in IR should notice that the interest in Peace and Conflict Studies indicates a move toward global questions in other social sciences, too. IR loses its claimed monopoly as the social science of global phenomena. But instead of turning this into new attempts of »disciplining«, the discipline should rather try to develop its internal pluralism and its social relevance.

Keywords: international relations, peace and conflict studies, scientific community, social sciences, globalization. 


\section{Harald Müller}

\section{No Chinese Walls}

On the Connection between Peace Research and International Relations

ZIB, Vol. 19, No. 1, pp. 153-168

There is no schism between Peace Research and International Relations. To the contrary, there are multiple interactions and interrelations, common interest in substance, and the challenge through current changes in the academic sector which both are confronted with. Even between Security Studies or Strategic Studies and Peace Research there exists no Chinese wall. Peace Research is distinct through its interdisciplinarity and the normative commitment to contribute to the reduction of violence; IR might share that goal, but it is not inevitably inscribed in its brief. In addition, Peace Research shares with its cousins practical interests and is involved in media communications and political consultancy. For future research, transdisciplinary »border walks« are of particular interest.

Keywords: peace research, normative orientation, transdiciplinarity, international relations, theory and practice.

\section{Tanja Brühl}

\section{Peace Research as »Super-Science« or a Sub-Discipline?}

On the Relationship of Peace Research and International Relations ZIB, Vol. 19, No. 1, pp. 169-181

The ZIB-Editors note that different focal points between International Relations (IR) and Peace Research (PCR) could result in a mutual speechlessness. In opposition to that argument I state that - at least since the early 1990s - there are intersections as well in subject as in acting people. There are similarities in theoretical, methodological and empirical assumptions and processes. Additionally, there are several scientists who feel at home in both IR and PCR. The exclusive assumptions of the 1970s are overcome in the ongoing professionalization in both disciplines. The intersections between IR and PCR are growing more than they decrease. As side effect of this phenomenon the non-intersecting areas of both disciplines tend to become more radical.

Keywords: international relations, peace research, scientific discourse, historical development, normative orientation. 
Christoph O. Meyer

Normative, Theoretical and Practical Deficits of Peace Studies: The Case of Conflict Prevention

ZIB, Vol. 19, No. 1, pp. 183-195

Peace Studies has the potential to theoretically and empirically enrich a core area of concern for International Relations (IR) as a discipline, which has become increasingly diverse over the years. The strand of Peace Studies, which is concerned with research for and not just on peace could also counter-balance the increasing tendency in IR towards paper rather than real problems. Unfortunately, Peace Studies does not always realise this potential as illustrated by the case of early warning for conflict prevention. The paper highlights deficits concerning normative assumptions about the desirability of conflict prevention, understandings of decision-making, and assumptions about when practitioners should heed advice. These problems are interrelated and partly caused by its demarcation from Security Studies. To enhance its credibility Peace Studies should reflect more on the impact its biases, open itself to insights from other fields such as Intelligence Studies and better separate knowledge claims from legitimate advocacy in public discourse.

Keywords: early warning, conflict prevention, peace studies, international relations theory, advocacy. 